\title{
From the hiatus in the theory - practice discourse to the clinic based on the uniqueness of knowledge
}

\author{
Do hiato no discurso teoria - prática à clinica baseada na unicidade do conhecimento
}

Del hiato en el discurso teoría - práctica a la clínica basada en la unicidad del conocimiento

Cristina Lavareda Baixinho ${ }^{1}($ D) António Pedro Costa ${ }^{2,3}$ (i)

1. Escola Superior de Enfermagem de Lisboa, Lisboa. Portugal.

2. Universidade de Aveiro. Aveiro, Portugal. 3. Ludomedia/webQDA

Corresponding author:

Cristina Lavareda Baixinho.

E-mail: crbaixinho@esel.pt

Submitted on 05/10/2019.

Accepted on 05/16/2019.

DOI: 10.1590/2177-9465-EAN-2019-0141
The discourse of health professionals continues to be marked by a hiatus between theory and practice, as if these were opposite entities. It would be expected that the proliferation of knowledge and its dissemination would diminish this gap, however it is still present in the speeches and even in the clinical decision-making where, often, one hears: the theory says... but experience leads me to take other options.

It is interesting to note that the proliferation of scientific studies and the dissemination of their results in health have undoubtedly contributed to improving care, increasing the average life expectancy, reducing mortality, morbidity and complications associated with chronic diseases, among others, ${ }^{1}$ but may it remain present this idea of the marked difference, and sometimes even antagonistic, between theory and practice. We believe that this dichotomy constitutes a false belief to justify the notion that the introduction of research results in contexts could be slow, sometimes prevailing the modus operandi of the routine, but that it is not associated with a devaluation of technical-scientific knowledge.

On the other hand, the variability between practice environments can make it difficult to introduce the results, produced in different contexts, by cultural differences, which has promoted a reflection on the results of the research and existing theories, emerging the notion of precariousness and outdatedness of the information which rapidly occurs. ${ }^{2}$

Simultaneously, intuition, little valued in the clinic, can contribute to the roots of this discourse, precisely by the undervaluation of a knowledge different from the empirical standard. Intuition has been described in the literature as the knowledge and feeling that enables decision-making without the use of the analytical-rational processing, increasing the capacity for judgment and decision-making. ${ }^{3}$ It combines the experience and the perceptions of the professional with the empirical knowledge and undoubtedly influences clinical decisionmaking.

To the detriment of the acceptance of this difference, we advocate that theory and practice are no more than two sides of the same coin and that intuitive knowledge reinforces empirical knowledge, maturing clinical decision-making, increasing quality and safety of care. It urges a paradigmatic rupture with this vision of a gap between two worlds (theoretical and practical), promoting reflection on practices, "ways of doing" and the consequences of the activity, using knowledge based on research, for decision-making. ${ }^{1}$

A clinic based on different patterns of knowledge can promote the uniqueness of knowledge. For this rupture, it is important that professionals are educated about the different standards of knowledge and their influence on decision-making, and that researchers and clinicians introduce to their work agenda the reflection on how the different types of knowledge promote the resolution of problems that emerge in praxis; to improve academic-practice communication networks; to promote the development of research skills in field professionals, to verify the adequacy of results to the needs of the end consumers, to develop "in loco" health research, to promote a research culturally congruent to the context, to increase health gains, to rapidly introduce results of the research, the desired evidence, in the clinic and feedback the knowledge with new knowledge. ${ }^{2}$ 


\section{REFERENCES}

1. Baixinho CL, Presado H, Ferreira Ó, Costa AP. Qualitative research and knowledge transfer - from project to decision-making?. Rev Bras Enferm [Internet]. 2019 feb; [cited 2019 apr 26]; 72(1):1-2. Available from: http:// www.scielo.br/scielo.php?script=sci_arttext\&pid=S003471672019000 100001\&lng=pthttp://dx.doi.org/10.1590/0034-7167.20197201
2. Baixinho CL, Ferreira Ó, Marques FM, Presado MH, Cardoso M, Sousa AD. Investigação Qualitativa e transferência do conhecimento para a clínica. In: Brandão C, Carvalho JL, Ribeiro J, Costa AP, organizadores. A prática na Investigação Qualitativa: exemplos de estudos. Oliveira de Azeméis (Portugal): Ludomedia; 2018. v.2. p.179-208.

3. Silva AL, Baldin SM, Nascimento KC. O conhecimento intuitivo no cuidado de enfermagem. Rev Bras Enferm [Internet]. 2003 feb; [cited 2019 apr 29]; 56(1):7-11. Available from: http://www.scielo.br/scielo.php?script=sci_arttext\&pid=S0034$71672003000100002 \&$ Ing=enhttp://dx.doi.org/10.1590/S003471672003000100002 